\title{
Maatalouden taaksepäin suuntautuneet arvonlisäysvaikutukset maakunnissa
}

\author{
Marja Knuuttila $^{1)}$ ja Eero Vatanen ${ }^{2)}$ \\ ${ }^{1)}$ MTT taloustutkimus, Lönnrotinkatu 5, 50100 Mikkeli, marja.knuuttila(at)mtt.fi, \\ ${ }^{2)}$ Itä-Suomen yliopisto, c/o Metla, PL 68, 80101 Joensuu, eero.vatanen(at)metla.fi
}

\section{Tiivistelmä}

Maatalouden osuus kansataloudessa on jatkuvasti pienentynyt tuotannon kasvaessa muilla toimialoilla maataloutta nopeammin. Samanaikaisesti maatalous on kuitenkin integroitunut muuhun talouteen aikaisempaa enemmän työnjaon lisääntymisen myötä. Maatalouden muilta toimialoilta ostamien tuotantopanosten ja maataloustuotteiden myynti välituotteina edelleen jalostettavaksi muilla toimialoilla on kasvanut. Tämä tarkoittaa sitä, että maatalouden ostojen ja myyntien kautta osa muiden toimialojen tuotannosta on kytköksissä maatalouteen. Tässä tutkimuksessa selvitettiin niitä maatalouden vaikutuksia muiden toimialojen tuotantoon, jotka syntyvät maatalouden hankkiessa panoksia (välituotteita) muilta toimialoilta. Näitä hankintoja kutsutaan toimialan taaksepäin suuntautuviksi kytkennöiksi ja niitä tutkitaan panos-tuotosanalyysin avulla. Tässä tutkimuksessa selvitettiin toimialan koko tuotoksen vaikutukset tuotosmallilla. Tutkimuskohteena olivat maatalouden tulo- eli arvonlisäysvaikutukset koko maassa ja maakunnissa. Tutkimus tuottaa tietoa maatalouden merkityksestä aluetaloudessa ja se on tärkeä myös alueiden tuotantorakenteiden hahmottamisen kannalta. Ostojen ja myyntien kautta tuotannonmuutokset yhdellä toimialalla heijastuvat myös muille toimialoille. Tutkimuksen tuottamaa tietoa voidaan hyödyntää maatalous-, maaseutu- ja aluepoliittisessa päätöksenteossa esimerkiksi ennakoitaessa maataloustuotannon muutoksen vaikutuksia aluetalouteen. Hankintojen eli tuotantoketjun taaksepäin suuntautuvien kytkentöjen avaamisella tutkimus myös tuottaa yksityiskohtaisempaa tietoa maatalouden kotimaisesta kustannusrakenteesta eli siitä, kuinka maatalouden kulut eri toimialoille kohdistuvat. Tietoa voidaan hyödyntää kotimaisessa elintarvikkeiden hinnanmuodostusta selvittävässä tutkimuksessa. Kotitaloudet ovat keskeinen toimija aluetaloudessa käyttäessään maataloudesta ansaittuja tuloja alueella, joten ne sisällytettiin yhtenä toimialana mukaan analyysiin. Aineistona käytettiin Tilastokeskuksen vuonna 2006 valmistunutta alueellista panos-tuotosaineistoa vuodelta 2002. Tutkimuksessa selvitettiin ensinnäkin sitä, kuinka suuret maatalouden taaksepäin suuntautuvien kytkentöjen kerrannaisvaikutukset ovat ja mille toimialoille ne ensisijaisesti kohdistuvat. Toiseksi selvitettiin sitä, kuinka suuria maatalouden taaksepäin suuntautuvat kerrannaisvaikutukset ovat suhteessa alueen muihin toimialoihin. Kolmanneksi, laskettiin tuotosmallilla maatalouden absoluuttiset bruttoarvonlisäysvaikutukset maakunnittain. Tutkimuksen tulokset osoittavat, että maatalouden taaksepäin suuntautuvista vaikutuksista selvästi suurimmat kohdistuvat kaupan alalle. Kauppa välittää tiloille suurimman osan maatalouden tarvitsemista panoksista. Yhtä maatalouden välitöntä arvonlisäysyksikköä kohden aiheutuu hankintojen ja kotitalouksien kulutuksen kerrannaisvaikutuksina välillistä arvonlisäystä koko maassa keskimäärin 0,69 yksikköä ja maakunnissa keskimäärin 0,39 yksikköä. Välillisesti eli maatalouden taaksepäin suuntautuvien kytkentöjen kautta toimialojen tuotannossa syntyy arvonlisäystä noin 1 miljardi euroa, mikä on enemmän kuin arvonlisäystä syntyy välittömästi maatalouden työn ja pääoman korvaukseksi markkinoilta saatuina myyntituloina ( $0.8 \mathrm{mrd}$. euroa). Maatalous ei kuitenkaan 27 toimialan välisessä vertailussa sijoittunut korkealle toimialan taaksepäin suuntautuvien kerrannaisvaikutusten määrässä. Maatalouden hankintojen vaikutukset olivat samankaltaisia eri maakunnissa. Alkuperäinen tutkimus sisälsi sekä maatalouden että metsätalouden taaksepäin suuntautuvien vaikutusten analyysin, joista tässä artikkelissa on raportoitu vain maatalouden tuloksia.

Asiasanat: maatalous, arvonlisäys, panos-tuotosanalyysi 


\section{Johdanto}

Toimialajaon avulla talous voidaan luokitella alkutuotantovaltaiseksi, teollistuneeksi tai palveluyhteiskunnaksi. Toimialajaon avulla ei kuitenkaan saada todellista kokonaiskuvaa eri alojen merkityksestä taloudessa. Nykyisin kaikki toimialat ovat yhä enemmän riippuvaisia toisistaan. Esimerkiksi maatalous ostaa tuotantopanoksia muilta toimialoilta ja myy maataloustuotteita edelleen jalostettavaksi muille toimialoille aikaisempaa enemmän. Tämä tarkoittaa sitä, että maatalouden ostot aiheuttavat osan muiden toimialojen tuotannosta ja toisaalta muiden toimialojen tuotanto on riippuvainen maatalouden tuotannosta myyntien kautta.

Tämän tutkimuksen tavoite oli selvittää millaiset kytkennät eli kerrannaisvaikutukset maatalouden ostoista seuraa muuhun talouteen. Tätä varten ensin selvitettiin, kuinka suuret maatalouden taaksepäin suuntautuvat kerrannaisvaikutukset ovat ja mille toimialoille ne ensisijaisesti kohdistuvat. Toiseksi selvitettiin sitä, kuinka suuria maatalouden taaksepäin suuntautuvat kerrannaisvaikutukset ovat suhteessa alueen muihin toimialoihin. Kolmanneksi, laskettiin tuotosmallilla maatalouden absoluuttiset arvonlisäysvaikutukset.

Maatalouden kerrannaisvaikutuksia on selvitetty aikaisemminkin jo 1980-luvulla, muttei yhtä järjestelmällisesti kaikkien maakuntien osalta (Kukkonen ja Lahdenperä 1986, Ruotsalainen 1989). Aiemmissa tutkimuksissa ei myöskään ole käytetty tuotosmallia, joka soveltuu perinteistä lopputuotekysyntämallia paremmin toimialan koko tuotoksen vaikutusten selvittämiseen.

Tutkimuksen taustalla on tarve saada tietoa maatalouden kerrannaisvaikutuksista. Ajoittaisesta kritiikistä huolimatta maatalous on edelleen yksi tärkeimmistä toimialoista maaseudun kehittämisen strategiaohjelmissa sekä kansallisesti että Euroopan Unionissa (EU) (OECD 2008). Kerrannaisvaikutukset täydentävät maatalouden työllisyyttä ja tulonmuodostusta, joten maaseudun kehittämisohjelmia varten tieto alan kerrannaisvaikutuksista on olennainen. Toinen peruste maatalouden kerrannaisvaikutusten tutkimiselle on maatalouden julkisen tuen aiheuttamien kerrannaisvaikutusten selvittäminen.

Toimialan merkitystä taloudessa kuvataan tuotoksen, arvonlisäyksen ja työllisyyden mittareilla. Tässä tutkimuksessa keskitytään arvonlisäykseen. Maatalouden työllisyysvaikutuksia on aiemmin tutkinut Knuuttila (2004). Maatalouden kokonaisarvonlisäysvaikutus muodostuu välittömästä ja välillisestä vaikutuksesta. Välitön vaikutus seuraa toimialan omasta tuotannosta ja välilliset vaikutukset, joita nimitetään myös kerrannaisvaikutuksiksi, syntyvät muiden toimialojen tuotteiden välituotekäytön seurauksena. Välituotekäytön eli panoshankintojen lisäksi kerrannaisvaikutuksia aiheutuu kotitalouksien käyttäessä tuotannossa syntyneitä tuloja kulutukseen. Näitä kotitalouksien ostoista aiheutuvia kerrannaisvaikutuksia kutsutaan kirjallisuudessa myös johdetuiksi vaikutuksiksi (Miller ja Blair 1985).

Seuraavassa luvussa Aineisto ja menetelmät kuvataan yksityiskohtaisesti tutkimuksessa käytettyä tutkimusmenetelmää ja aineistoa. Luvussa Tulokset ja tulosten tarkastelu kuvataan tutkimuksen keskeisimpiä tuloksia ja niiden merkitystä. Viimeisessä luvussa esitetään johtopäätökset ja jatkotutkimustarpeet.

\section{Aineisto ja menetelmät}

\section{Kokonaistuotosmalli (perus- ja laajennettu)}

Yrityksien tuottamat hyödykkeet määritellään niiden käyttötarkoituksen ja käyttöalueen perusteella väli- ja lopputuotteiksi. Välituotteet ovat tuotteita, jotka myydään aluetalouden toimialoille käytettäviksi niiden tuotteiden valmistuksessa. Tutkimuksessa määritetyn aluetalouden näkökulmasta kaikki tuotteet, jotka viedään pois alueelta, ovat lopputuotteita. Lopputuotteita ovat lisäksi kotitalouksien ja julkisten yhteisöjen kulutukseen sekä investointeihin käytetyt tuotteet. Perusmallissa kotitalouksien kulutus on eksogeenista eli ne eivät ole funktionaalisessa riippuvuussuhteessa mallin tuotannollisiin toimialoihin. Laajennetussa mallissa myös kotitaloudet määritellään funktionaaliseen riippuvuussuhteeseen tuotannollisiin toimialoihin. Eli ne myyvät työvoimaa ja muita tuotannontekijöitä tuotannollisten toimialojen käyttöön ja saavat korvaukseksi tuloja, joita kotitaloudet käyttävät toimialojen tuotteiden ostoihin.

Perinteisessä panos-tuotosmallissa toimialojen tuotokset määräytyvät niiden lopputuotteiden kysynnän ja toimialojen keskinäisen riippuvuuden osoittamien kertoimien suhteena. Toimialojen tuotoksesta osa kuitenkin tuotetaan välituotteeksi muiden toimialojen tuotteiden valmistamista varten. Tällöin toimialojen väliset suhteet voivat rakentua myös niin, että jotkut toimialat tuottavat pelkästään 
välituotteita, jolloin näiden toimialojen kokonaisvaikutuksia ei voida arvioida perinteisen panostuotosmallin avulla. Lisäksi lopputuotekysyntään suhteutettujen kertoimien käyttö toimialan tuotoksen vaikutuksien arvioinnissa yliarvioi toimialan tuotosvaikutuksen liian suureksi. (Szyrmer 1992, Oosterhaven ja Stelder 2002, Miller ja Blair 2009, 625).

Kokonaistuotosmalli on perinteisen Leontiefin panos-tuotosmallin sovellus, jonka avulla voidaan määrittää, kuinka samanlaisia tuotteita valmistavien yrityksien muodostamien toimialojen tuotokset vaikuttavat toisten toimialojen tuotoksiin. Kokonaistuotosmallin kehitystyötä ovat edesauttaneet mm. Tiebout (1969), Ritz ja Spaulding (1975, ks. Miller ja Blair 1985 s. 328 ja Szyrmer 1992 s. $927-$ 928), Schultz (1977), Milana (1985), Szyrmer (1986, 1992) ja Vatanen (1991, 1992, 2001).

Kokonaistuotosmallin lähtökohtana olevan panos-tuotosmallin toimialakohtaiset tuotokset ovat riippuvaisia kaikkien toimialojen lopputuotekysynnöistä ja tarkasteltavan talouden toimialojen keskinäisistä riippuvuuksista (panoskäytöstä):

$$
\mathbf{X}=(\mathbf{I}-\mathbf{A})^{-1} \mathbf{Y}
$$

missä

$\mathbf{X}=$ toimialojen tuotoksien (tulojen) vektori,

$\mathbf{Y}=$ toimialojen lopputuotekysyntöjen vektori ja

$(\mathbf{I}-\mathbf{A})^{-1}=$ toimialojen keskinäisiä riippuvuuksia kuvaava kerroinmatriisi,

ns. Leontiefin käänteismatriisi, jossa $\mathbf{I}$ on yksikkömatriisi ja $\mathbf{A}$ on panoskerroinmatriisi $\left(\mathbf{A}_{\mathbf{i j}}=\mathbf{Z}_{\mathrm{ij}} / \mathbf{X}_{\mathbf{j}}\right)$, jossa $\mathbf{Z}_{\mathbf{i j}}$ on toimialan $\mathbf{X}_{\mathbf{i}}$ tuotoksen käyttö toimialan $\mathbf{X}_{\mathbf{j}}$ välituotepanoksena).

Kokonaistuotosmalli voidaan esittää kätevimmin Szyrmerin (1992) ns. total flow TF -matriisin avulla. TF -matriisi on Leontiefin panos-tuotosmallin käänteismatriisin. muunnos. Kun kyseessä on toimialojen tuotoksien riippuvuus toimialojen tuotoksista, eikä lopputuotekysynnöistä, kunkin toimialan tuotoksen riippuvuus itsestään on ykkösen suuruinen, ja vastaavasti kunkin toimialan tuotoksen kokonaisvaikutus muihin tuotoksiin on pienempi kuin vastaavan toimialan lopputuotekysynnän vaikutukset muiden toimialojen tuotoksiin. Formaalisti muunnos suoritetaan jakamalla Leontiefin matriisin sarakkeiden luvut saman matriisin diagonaaliluvuilla eli matriisilaskentaa käyttäen:

$$
\mathbf{T F}=(\mathbf{I}-\mathbf{A})^{-1}\left((\mathbf{I}-\mathbf{A})_{\mathrm{jj}}^{-1}\right)^{-1}
$$

missä $\left((\mathbf{I}-\mathbf{A})_{\mathrm{jj}}^{-\mathbf{1}}\right)^{-\mathbf{1}}$ on Leontiefin käänteismatriisin $(\mathbf{I} \text { - A })^{-1}$ diagonaalivektorista muodostetun diagonaalimatriisin käänteismatriisi.

Kerrannaisvaikutusten analysoimisessa TF -matriisia käytetään kuten perinteistä Leontiefin käänteismatriisia (ks. yksityiskohdat esim. Forssell 1985 tai Miller ja Blair 1985, 2009 ). TF -matriisin sarakesummat eli tuotantokertoimet osoittavat, miten sarakkeen toimialan tuotosyksikkö edellyttää tuotantoa talouden eri toimialoilla yhteensä, kun Leontiefin käänteismatriisissa tarkastelu kohdistetaan lopputuoteyksikköön. Tuotantokertoimien vertailu osoittaa, millaiset ovat kunkin toimialan tuotosyksikön aiheuttamat kokonaisvaikutukset suhteessa toisiinsa.

Panos-tuotosanalyysissä on otettava huomioon, että panos-tuotosmalli perustuu talousteorian näkemykseen, että lopputuotteiden kysyntä on taloudellisen toiminnan alkuperäinen syy. Ilman hyödykkeiden kysyntää ei ole niiden tuotantoa. Syy ja seuraus -suhde on kysynnästä tuotantoon eli tuotantoketjussa taaksepäin. Myös mallin avulla arvioitavat tuotannollisten toimialojen väliset suhteet ovat määrittyneitä kysynnästä tuotantoon eli taaksepäin suuntautuviksi. Myös kokonaistuotosmallissa tuotokset määrittyvät viime kädessä niiden kysyntöjen kautta, vaikka vaikutukset kohdennetaan tuotosyksikköön. Szyrmerin (1992) mukaan tuotostarkastelussa on ensisijaisesti kyse ex post -tarkastelusta eli siinä kuvataan niitä vaikutuksia, jotka ovat assossioituneet tarkasteltavan toimialan tuotokseen ja muutosanalyysissä tuotoksen muutokseen.

Suhteellisten kerrannaisvaikutusten lisäksi kokonaistuotosmallin avulla voidaan määrittää toimialan tuotoksen bruttovaikutukset taloudessa, kun tarkastellaan tuotosyksikön sijasta koko tuotosta. 
Toimialan tuotoksen muille toimialoille aiheuttama tuotosvaikutus saadaan kertomalla TF -matriisilla tuotoksista muodostettu diagonaalimatriisi $\hat{\mathbf{X}}$ :

$$
\mathbf{R}=(\mathbf{T F}) \hat{\mathbf{X}}
$$

missä $\mathbf{R}$ on tuotosvaikutusmatriisi eli tuotoksen analyysimatriisi, jonka diagonaalisoluissa ovat toimialojen tuotokset, ja sarakkeen ei-diagonaalisolut osoittavat, miten sarakkeen toimialan tuotos on edellyttänyt tuotosta rivien toimialoilta. Sarakesumma muodostaa toimialan kokonaisvaikutuksen talouteen bruttona. Toisin sanoen se kuvaa sitä vaikutusta, mikä taloudessa menetettäisiin, jos toimiala yhtäkkiä häviäisi taloudesta. (Vatanen 2001).

Tutkimuksen perusaineisto on Tilastokeskuksen vuoden 2002 maakunnallinen 30 toimialan panostuotosaineisto (Tilastokeskus 2009). Aineistossa maataloutta edustaa toimiala 01 Maatalous, riistatalous ja niihin liittyvät palvelut.

\section{Tulokset ja tulosten tarkastelu}

Tuloksia tarkastellaan koko maan tasolla ja maakunnissa. Maakunnissa kerrannaisvaikutukset jäävät koko maan keskimääräistä pienemmiksi. Tämä johtuu siitä, että maakunnissa tuotannon ja kysynnän vaikutuksista osa kohdistuu aina kotimaisen tuonnin seurauksena toisaalle kotimaassa.

Yhtä maatalouden välitöntä arvonlisäysyksikköä kohden aiheutuu hankintojen ja kotitalouksien kulutuksen kerrannaisvaikutuksina välillistä arvonlisäystä koko maassa keskimäärin 0,69 yksikköä ja maakunnissa keskimäärin 0,39 yksikköä. Maatalouden suhteelliset kerrannaisvaikutukset arvonlisäyksellä mitattuna jäävät pienemmiksi kuin kaikkien toimialojen keskimääräiset kerrannaisvaikutukset. Kaikkien toimialojen hankintojen ja kotitalouksien ostojen välillisten vaikutusten keskiarvo koko maassa oli 1,02 ja maakunnissa tämä keskiarvo oli keskimäärin 0,63 . Maatalouden ja muiden toimialojen välisen eron syy kerrannaisvaikutusten määrässä on ensisijaisesti toimialojen hankintojen erilaiset jakaumat.

Hankintojen kerrannaisvaikutusten määrään vaikuttaa toimialan tuotantoteknologia ja hankintojen kohdistuminen maakuntaan. Pääsääntö on, että mitä enemmän ala hankkii välituotteina tarvittavia panoksia muilta aloilta suhteessa alan omaan työ- ja pääomakorvaukseen, sitä suuremmat ovat tuotannon kerrannaisvaikutukset. Maatalous on pääomaintensiivinen ala. Suunnitelmanmukaiset kone- ja rakennuspoistot ovat noin 20 prosenttia kokonaistuotosta (Taloustohtori 2009, Niemi ja Ahlstedt 2009). Tämä osaltaan selittää maatalouden hankintojen kerrannaisvaikutusten pientä määrää.

Maatalouden hankinnat jakaantuvat oman maakunnan lisäksi muualle kotimaahan ja ulkomaan tuontiin. Aloja, jotka kotimaassa ja maakunnissa eniten hyötyvät maatalouden tuotannosta ovat maatalouskauppa, rehuteollisuus, kuljetusala ja erilaiset liike-elämän palvelut. Näille toimialoille suuntautuu 73 prosenttia maatalouden hankintojen vaikutuksista. Kaupan rooli on merkittävä sillä maatalouden hankintojen vaikutuksista keskimäärin 35 prosenttia kohdistuu kaupan alalle. Koska kerrannaisvaikutukset määritelmällisesti kattavat maatalouden hankintojen lisäksi ne alat, jotka tuottavat panoksia maatalouden panostoimittajille ja niin edelleen koko vaikutusketjun loppuun saakka, yltävät maatalouden välilliset vaikutukset kaikkialle tehdasteollisuutta, erilaisia palveluja ja terveydenhuoltoa myöten (Kuvio 1). 


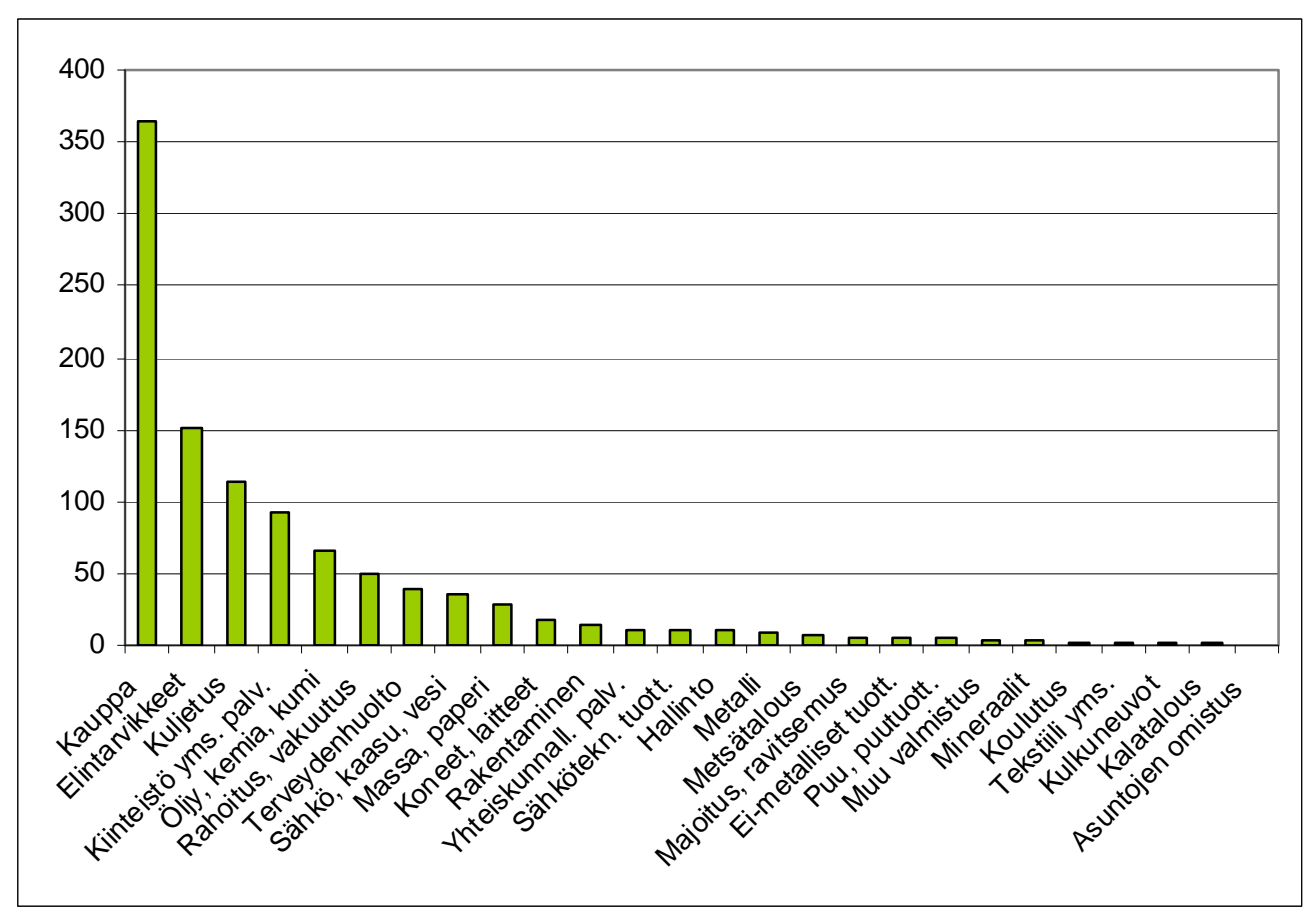

Kuvio 1. Maatalouden hankintojen kerrannaisvaikutusten (yhteensä 1 miljardi euroa) kohdentuminen eri toimialoille koko maassa vuonna 2002, (arvonlisäys milj. €).

Maatalouden maakunnalliset hankintojen vaikutukset olivat samankaltaisia. Maatalouden kerrannaisvaikutuksen suuruus ei vaihdellut paljon maakunnasta toiseen, toimialojen välisessä vertailussa maatalous sijoittui mediaanin alapuolelle ja aloissa, joihin kerrannaisvaikutukset kohdistuivat, ei ollut suuria eroja maakuntien välillä. Tämä selittyy osin sillä, että hankintojen kohteena olevista aloista osa on selkeämmin paikallisia. Esimerkiksi maatalouskauppa, jonka kautta valtaosa maatalouden tarvitsemista tarvikkeista kulkee, on tyypillisesti paikallista. Samoin kuljetusalalla esimerkiksi maidon ja eläinten kuljetusautot ovat paikallisia yrityksiä.

Kotitalouksien maataloudesta ansaitsemien tulojen käytön vaikutukset ovat tärkeä osa maatalouden kerrannaisvaikutuksia maakunnissa. Kun hankinnoissa yhtä maatalouden välitöntä tulo- eli arvonlisäysyksikköä kohden syntyi tuloa 0,19 yksikköä, niin kotitalouksien ostoissa tämä oli 0,20 yksikköä. Kotitalouksien ostojen vaikutukset maakunnassa ovat riippuvaisia maataloudessa ansaittujen tulojen määrästä ja kotitalouksien ostojen kohdistumisesta maakuntaan. Kotitalouksien ostojen vaikutuksista hankintoja hieman suurempi osuus eli 61 prosenttia kohdistui maakuntiin vastaavan osuuden hankinnoissa ollessa 57 prosenttia. Hankintojen tavoin kauppa ja kuljetusala ovat aloja, jotka hyötyvät kotitalouksien kulutuksesta.

Maatalouden kerrannaisvaikutusten suuruutta havainnollistaa se, että maatalouden hankinnoissa syntyy tuloa koko maassa välillisesti 1049 miljoonaa euroa ja kotitalouksien kulutuksen kautta 951 miljoonaa euroa eli yhteensä 2 miljardia euroa. Maatalouden välitön arvonlisäys eli työlle ja pääomalle saatu korvaus on 2,9 miljardia euroa. Maatalouden kokonaisvaikutus talouteen arvonlisäyksellä mitattuna on siten yhteensä 4,9 mrd. euroa.

\section{Johtopäätökset}

Kotitalouksien kulutusvaikutus on merkittävämpi osa kuin hankintojen välilliset vaikutukset maatalouden kokonaisarvonlisäyksistä maakunnissa. Sekä maatalouden hankintojen että kotitalouksien kulutuksen vaikutuksista osa vuotaa maakunnan ulkopuolelle kotimaahan ja ulkomaille.

Tämän tutkimuksen tulokset eivät osoittaneet merkittäviä eroja maakuntien välisissä maatalouden kerrannaisvaikutuksissa, vaikka tuotannossa on alueellista keskittymistä tuotantosuunnittain ja kustannusten osuus ja rakenne poikkeavat eri tuotantosuuntien välillä. Kerrannaisvaikutusten tuotantosuuntien välisten erojen tutkiminen edellyttäisi Tilastokeskuksen koko toimialan tilastotietoja yksityiskohtaisempaa aineistoa tuotantosuuntien mukaan. 
Tässä tutkimuksessa ei tutkittu maatalouden raaka-aineen jalostuksen vaikutuksia maakunnan talouteen. Maatalouden tulonmuodostuksen tutkiminen ilman jalostusvaikutuksia ei anna riittävää kuvaa maatalouteen integroituneesta tulonmuodostuksesta makunnissa. Maatalouden suhteellinen asema maakunnan taloudessa muuttuu, kun myös maatalouden tuottaman raaka-aineen jalostuksen nettovaikutukset otetaan huomioon. Maatalouteen liittyvää tulonmuodostusta tulisikin lähestyä tuotantoketju- tai sektorinäkökulmasta, jossa myös raaka-ainetta jalostava teollisuus sisällytetään analyysiin.

Maataloudesta johtuvan tulon tarkastelu ei ollut täydellinen siinäkään mielessä, että kerrannaisvaikutuksiin ei tässä tutkimuksessa sisältynyt maatalouden ja sille välituotteita tuottavien alojen investointien vaikutukset. Investointien sisällyttäminen mukaan tarkasteluun laajentaisi maataloudesta johtuvaa tuloa edelleen uusille aloille. Maatalouden ja sille välituotteita toimittavien alojen investointivaikutusten selvittämistä hankaloittaa etenkin se, ettei maatalouden tai muidenkaan alojen kone- ja rakennusinvestoinneista ole käytettävissä aluetason tilastotietoja.

\section{Kirjallisuus}

Forssell, O. 1985. Panos-tuotosmallit. ETLA Elinkeinoelämän tutkimuslaitos, B 46, Helsinki: ETLA. 130 s. Knuuttila, M. 2004. Elintarvikesektorin työllisyysvaikutukset - Panos-tuotosanalyysi maakunnittain. Maa- ja elintarviketalous 56.87 s., 17 liitettä. Maa- ja elintarviketalouden tutkimuskeskus.

Kukkonen, P. \& Lahdenperä, H. 1986. Maa- ja metsätalouden kerrannaisvaikutukset kansantaloudessa. Teoksessa: Maa- ja metsätalous kansantaloudessa. Pellervon taloudellisen tutkimuslaitoksen julkaisuja n:o 6. Espoo: Pellervon taloudellinen tutkimuslaitos. s. 84-109.

Milana, C. 1985. Direct and indirect Requirements for gross output in input-output analysis. Metroeconomica 37: 283-292.

Miller, R.E. \& Blair, P.D. 1985. Input-Output Analysis; Foundations and Extensions. New-Jersey: PrenticeHall. $464 \mathrm{~s}$.

Miller, R.E. \& Blair, P.D. 2009. Input-Output Analysis; Foundations and Extensions. 2. painos. Cambridge University Press. $750 \mathrm{~s}$.

Niemi, J. \& Ahlstedt, J. (toim.) 2009. Suomen maatalous ja maaseutuelinkeinot 2009. MTT Taloustutkimus julkaisuja 109. Helsinki: MTT. $96 \mathrm{~s}$.

OECD. 2008. OECD Rural Policy Reviews Finland. Paris: OECD. $302 \mathrm{s.}$

Oosterhaven, J. \& Stelder, K. 2002. Net Multipliers Avoid Exaggerating Impacts: With a Bi-Regional Illustration for the Dutch Transportation Sector. Journal of Regional Science 42: 533-543.

Ritz, P. \& Spaulding, E. 1975. Basic I-O Terminology. Unpublished memorandum, U. S. Department of Commerce, Bureau of Economic Analysis, Interindustry Economics Division, February 25.

Ruotsalainen, P. 1989. Maa- ja metsätalouden merkitys Suomessa: alueellinen panos-tuotosanalyysi. Pellervon tutkimuslaitos. Raportteja ja artikkeleita N:o 82. Espoo: Pellervon tutkimuslaitos. $74 \mathrm{~s}$.

Schultz, S. 1977. Approaches to Identifying key Sectors Empirically by Means of Input-Output Analysis. The Journal of Development Studies 1: 77-96.

Szyrmer, J. 1986. Measuring connectedness of input-output models: 2. Total flow concept. Environment and Planning A 18: 107-121.

Szyrmer, J. 1992. Input-output coefficients and multipliers from a total-flow perspective. Environment and Planning A 24: 921-937.

Taloustohtori 2009. Maa- ja elintarviketalouden tutkimuskeskus. Saatavissa internetistä: www.mtt.fi/taloustohtori/kannattavuuskirjanpito

Tiebout, C. 1969. An Empirical Regional Input-Output Projection Model: The State of Washington. The Review of Economics and Statistics 51(3): 334-340.

Tilastokeskus 2009. Alueellinen panos-tuotos. Saatavissa internetistä: http://www.stat.fi/til/apt/index.html. Vatanen, E. 1991. Metsäsektorin merkitys: Mittaamisen menetelmiä. Keskustelualoitteita N:o 19. Joensuu: Joensuun yliopisto. Kansantaloustiede. $47 \mathrm{~s}$.

Vatanen, E. 1992. Metsäsektori talouden arvonlisäyksessä. Mittausmenetelmien empiirisiä kokeiluja. Keskustelualoitteita. N:o 22. Joensuu: Joensuun yliopisto. Kansantaloustiede. $27 \mathrm{~s}$.

Vatanen, E. 2001. Puunkorjuun ja puunkuljetuksen paikallistaloudelliset vaikutukset Juvan, Keuruun ja Pielisen Karjalan seutukunnissa. Metsäntutkimuslaitoksen tiedonantoja 825. Joensuu: Metsäntutkimuslaitos, Joensuun tutkimuskeskus. $73 \mathrm{~s}$. 